\title{
PRIVACY IN PUBLIC SPACE: CONCEPTUAL AND REGULATORY CHALLENGES. TIMAN, T.; NEWELL, B. C.; KOOPS, B.-J. (EDS.)*
}

by

JAKUB MÍŠEK

Timan, T.; Newell, B. C.; Koops, B.-J. (eds.). (2017) Privacy in Public Space: Conceptual and Regulatory Challenges. Cheltenham: Edward Elgar Publishing, $315 p$.

Privacy in Public Space is the eighth contribution in the Elgar law, technology and society series, published by Edward Elgar Publishing. The book is a collective monograph consisting of 10 chapters written by different authors, divided into two parts. Overlaying theme of the book is a challenge for privacy in public spaces that was brought by technological advancements. The book does not elaborate on privacy issues of online or virtual environment. The chapters are strictly focused on the technology-based intrusions of privacy in the actual physical world. Chapters in the first part, called Philosophical and Empirical Insights, are generally more theoretical and try to take new approaches in debating the topic. On the other hand, chapters in the second part, named Law and Regulation, describe specific legal problems, often comparing European and American way of regulation. The chapters are accompanied by an introduction (written by the editors) ${ }^{1}$ and conclusion (written by Timan Tjerk) ${ }^{2}$, which aims to bind the whole book together and provide a unifying frame.

\footnotetext{
This review was created with the support of Masaryk University Grant No. MUNI/A/1015/2017.

** jkb.misek@mail.muni.cz, Ph.D. candidate and lecturer at the Institute of Law and Technology on Masaryk University, Brno, the Czech Republic.

See p. 1-15 of the book.

2 See p. 269-290 of the book.
} 
The biggest problem of the publication, and in my opinion the only major problem of it, is that this binding and framing together does not really work well. The book is a mosaic of ideas and topics. Some of them are more prominent (like a notion of wearing masks which is a main theme of chapters 2 and 7 , but can be found also in others ${ }^{3}$, or accenting of the necessity of thinking about privacy in a specific context), some of them appear only to disappear and be absent for the rest of the book (human geography approach as is presented in the chapter 1). That is problematic for two reasons. Firstly, because of this issue, many questions remain unanswered. For example, it might be very interesting to read more about the mentioned human geography context, because the first chapter is only an introduction to the topic. However, next chapters do not follow up on that, but offer new themes and thought-provoking ideas concerning privacy in public. Absence of more thorough elaboration on specific issues leads to a certain disappointment. Secondly, it is not clear, why are these specific chapters (and topics they present) parts of the book or what is their role within it. Why were these specific texts chosen? Was that just because they were good on their own, or was there a higher intent? It is interesting that almost a third of the publication consists of texts which were previously published somewhere else (chapters $8^{4}, 9^{5}$ and $10^{6}$ ). There are chapters which present a brand-new approach to understanding of privacy (e.g. chapter 1), chapters which summarise current state of knowledge (chapter 6) and chapters which look into the future and try to predict next development (chapter 10). Tjerk writes in the Conclusion that

"The common denominator in this book is that this data gathering happens in public space."

\footnotetext{
E.g. part 3.1 of chapter 4 (pp. 98-101) where the author writes about self-protection measures for ensuring one's privacy in public space.

4 The chapter is an abridged and updated version of paper Froomkin, A. M. (2015) Regulating Mass Surveillance as Privacy Pollution: Learning from Environmental Impact Statements. University of Illinois Law Review, 67(5), pp. 1713-1790.

5 Parts of the chapter come from Scherr, A. E. (2013) Genetic Privacy and the Fourth Amendment: Unregulated Surreptitious DNA Harvesting. Georgia Law Review, 47(2), pp. 445-526.

6 Original version was published as Jones, M. L. (2015) Privacy without Screens \& the Internet of Other People's Things. Idaho Law Review, 51(3), pp. 639-660.

7 See p. 274 of the book.
} 
All of the chapters truly fit into this description, most of them are interesting and bring good critical insights, but they just do not interplay between each other.

Because of this problem, the book is in fact closer to conference proceedings than to a monograph. It might not be a problem if the reader has adequate expectations. ${ }^{8}$ However, chapters, or more precisely papers, present in the book are generally worth reading as the authors managed to bring forth interesting ideas and they discussed them properly.

In following paragraphs there are described in more detail four chapters which in my opinion were most interesting and show well width of topics and approaches present in the book. In chapter 2, named Hidden in a plain sight, Michael Nagenborg focuses on

"philosophical perspective on the usage of masks in the context of resistance to surveillance".

Nagenborg in his historical-philosophical analysis starts from the perspective that a mask is a tool used both for hiding (and obtaining anonymity as an individual) and recognizability (and obtaining identity as a member of a group). In this meaning the masks were used in ancient Rome, as well as in classic Shakespearean theatre and most recently during mass protests and civic uprisings (good examples are Anonymous masks in the shape of famous Guy Fawkes's mask or pasamontana used by the members of the Zapatistas movement). An interesting twist is brought by new technologies, especially mass surveillance of public places that is made possible thanks to a system of different types of cameras (e.g. long-distance CCTV, wearables etc.). In this context, Nagenborg mentions specific kinds of masking for which he uses the word camouflage ${ }^{10}$. It

"aims for making faces unreadable to machines by exploiting some of the underlying assumptions of face-recognition algorithms."11

This technique uses ahighly stylized make-up and hair styling, so the automatic system cannot recognise the face as a face. As the author

8 The back cover of the book states that its content is created by multiple authors with different approaches so in this matter the book tries to set the expectations right.

9 See p. 49 of the book.

10 See p. 58 of the book.

11 Ibid. 
correctly mentions, this action is not helpful against human eyes; on contrary it brings attention to the wearer. However, this can be understood as a clear act of communication by which the wearer claims that she does not want to be automatically identified. We can see there a parallel with the "do not track" principles we meet in the context of online privacy.

In the book, there is a number chapters that provide a good comparative study of differences in legal regulation in Europe and in the United States. One of them is chapter 7 (Covering up: American and European approaches to public facial anonymity after $S A S v$. France) by Angela Daly, which is also directly connected with chapter 2 , because it is concerned with right to cover one's face when being in public spaces. Daly analyses decision of the European Court of Human Rights in SAS v. France $^{12}$, in which the Court decided that prohibition of wearing of clothing designed to conceal one's face in public places does not violate basic human rights guaranteed by the Convention. Even though in this case was disputed wearing of Muslim face veils, the wording of the act in question is much broader and thus it applies on "any facial covering worn for any motivation"13. Unfortunately, as the author correctly mentions, the question of surveillance was not raised during the proceedings and thus it was not part of a balancing test. Daly then compares European regulation with anti-mask laws in the US. She explains different contexts of creation of such laws and what different outcomes would have similar situations. The writing is very clear and comprehensible, pointing out important facts. Unfortunately, the author did note use this opportunity to address the problem from the practical position of anti-surveillance camouflage. She mentions this only briefly in one paragraph at the very end of the chapter, saying that the solution is not clear, but that

"the SAS v. France decision does not seem to give a solid fundamental rights basis to using identity-obscuring techniques in Europe."

This is a missed opportunity. The chapter is a practical legal analysis, the author prepares ground that can be used for following argumentation

\footnotetext{
12 Judgment of 1 July 2014, S.A.S. v. France, application no. 43835/11. Available from: http://hudoc.echr.coe.int/eng?i=001-145466

13 Ibid; see p. 167 of the book.

14 Ibid; see p. 182 of the book.
} 
concerning allowance of anti-surveillance camouflage and then she decides to leave the questions open without even attempting to answer them.

A. Michael Froomkin in chapter 8 (Privacy Impact Notices to address the privacy pollution of mass surveillance) provides another interesting comparison of the European and US law when he tries to find a regulatory method which would be applicable in the US to combat mass surveillance. His starting point is that for number of reasons the US legislator will never accept European system, which might not be perfect, but is currently better suited for solving this issue. Froomkin therefore proposes that a possible way in the US might be to take inspiration from the local environmental protection regulation. Companies which conduct such surveillance should have a new duty to create in certain situations Privacy Impact Notices which will help to inform people about their data and their value. There are two points I would like to mention. Firstly, the author offers a list of data processing types which are categorically excluded from this duty. Some of the types are very specific (e.g. sporting events or surveillance of persistent protest) and from European point of view this is quite surprising, because regulation based on more abstract rules using a purpose as a regulatory cornerstone is much more flexible with maintaining of the same effect (in abovementioned examples the same purpose can be e.g. journalism). Secondly, connecting privacy data protection with environmental protection confirms the idea that personal data protection is (at least in part) a non-distributive right (a public good). ${ }^{15}$

Meg Leta Jones in chapter 10 (The Internet of other people's things) also compares European and American approaches to the privacy law and regulation of public spaces. Her chapter is focused on the near future, in which most of the screens of devices will be replaced by tangible, ambient computing. With that will be threatened one of the basic premises of personal data and privacy protection- informed privacy self-management. Leta Jones cites Daniel Solove and other authors and reminds the reader that even now, when we have screens with information available, is this concept problematic, at least. However, disappearance of screens will dissolve even this little basic justification. The author sees this as an opportunity, because the change is so big that it might create a new technological momentum, a phase during which a new technological

15 For more information, in Czech, see Polčák, R. (2012) Internet a proměny práva. Praha: Auditorium, p. 342. 
standard is set. If we are careful, the new standard can be designed in a way that it can overcome flaws of informed consent concept. Meg Leta Jones argues well what is needed to be done and is optimistic about the future. It is a really good paper, highly recommended to read.

The other chapters continue in the trend of very broad span of both thematic and methodological approaches. As examples can serve abovementioned chapter $1^{16}$, in which Bert-Jaap Koops and Maša Galič take as a starting point human geography, chapter $4^{17}$, in which Karsten Mause uses law and economics approach, and chapter $5^{18}$, where Julia M. Hildebrand elaborates on the concept of "privacy bubbles" in the light of law and humanities approach.

Privacy in Public Space offers several interesting chapters (papers) in which authors provide insights from different fields and areas connected with privacy and publicity. The editors did a good work in selecting papers present in the monograph. Unfortunately, the chapters are not very connected together. If they were, the book would be more compact, more balanced and might have been even better in general, because the unanswered questions, which remained now, might have their answers there. However, in spite of that, the book contains a richness of information and for that it can be recommended.

\section{LIST OF REFERENCES}

[1] Froomkin, A. M. (2015) Regulating Mass Surveillance as Privacy Pollution: Learning from Environmental Impact Statements. University of Illinois Law Review, 67(5), pp. 1713-1790.

[2] Jones, M. L. (2015) Privacy without Screens \& the Internet of Other People's Things. Idaho Law Review, 51(3), pp. 639-660.

[3] Judgment of 1 July 2014, S.A.S. v. France, application no. 43835/11. Available from: http://hudoc.echr.coe.int/eng?i=001-145466

[4] Polčák, R. (2012) Internet a proměny práva. Praha: Auditorium, 392 p.

[5] Scherr, A. E. (2013) Genetic Privacy and the Fourth Amendment: Unregulated Surreptitious DNA Harvesting. Georgia Law Review, 47(2), pp. 445-526.

\footnotetext{
16 The name of the chapter is Conceptualizing space and place: lessons from geography for the debate on privacy in public.

17 The chapter is called A politico-economic perspective on privacy in public spaces.

18 The chapter is named Visually distant and virtually close: public and private spaces in the Archives de la Planete (1909-1931) and Life in a Day (2011).
} 